Michael R. Ott

\title{
Culture in Nature: Writing on Wood
}

Apart from Scandinavia with its enduring runic tradition, most medieval literatures have little use for wooden inscriptions. This may come as a surprise given the ubiquity of such artefacts in the Middle Ages, which even lend their name to writing and written objects: etymologically, the Brothers Grimm proposed, the German word for letter (Buchstabe) and terms like Gothic bôka and Old Saxon buok derive from the early Germanic words for "beech tree” (Buche in present-day German). ${ }^{1}$ Moreover, inscriptions in wood feature prominently in both antiquity and the early modern period, where we witness a large amount of narrated tree inscriptions especially in Pastoral poetry. These pastorals were closely linked to ancient textual traditions which were rarely available in the Middle Ages. ${ }^{2}$ Consequently, there is a gap in vernacular literary history concerning tree inscriptions and wooden inscriptions in general, ${ }^{3}$ beginning roughly with Vergil's Eclogues (c.40 BCE) and ending with the Pastoral renaissance of the fourteenth and fifteenth century (e. g. Petrarch, Sannazaro, Boiardo) which subsequently shaped Europe's literary landscape.

This article examines some medieval exceptions in this void, turning first to the Scandinavian runic tradition and the Continental reminiscence of wood's magical power. Secondly I examine the sad, short, love story between the nymph Oenone and Paris, as retold in several accounts of the Trojan War. Finally, I take a closer look at Marie de France's and Gottfried von Straßburg's stories of Tristan and Iseult, both of which present letters on wood as a form of secret communication.

Although there is little evidence with which to develop a broader argument about inscriptions on wood, this scarcity is itself worth considering. In fact, instead of lamenting the sparsity of examples, we should make an argument of it. The rareness of writing on wood, I propose, is due to wood's categorisation as part of the realm of nature rather than culture. As such, wood is a counterpart to the courtly sphere with

1 For more information on etymology and etymological discussions see Pierce 2006.

2 For the ancient tradition see Kruschwitz 2010. For the early modern renewal of the ancient tradition see Doblhofer 1996.

3 Except for one example from Saxo Grammaticus and some Latin words in a Carmina Burana poem, this article won't cover medieval Latin literature. In his book on the inscriptio arguta, a certain type of baroque genre, Thomas Neukirchen hints to one wooden inscription by the Frankish poet Moduin, see Neukirchen 1999, 190.

This publication originated in the Collaborative Research Centre 933 "Material Text Cultures. Materiality and Presence of Writing in Non-Typographic Societies" (subproject C05 “Inscriptionality. Reflections of Material Text Culture in the Literature of the 12th to 17th Centuries"). The CRC 933 is funded by the German Research Foundation (DFG).

Ә Open Access. (c) 2019 Michael R. Ott, published by De Gruyter. (c) BY-NC-ND This work is licensed under the Creative Commons Attribution-NonCommercial-NoDerivatives 4.0 License.

https://doi.org/10.1515/9783110645446-008 
its learned writing culture that heavily relies on prepared skin, monastic education, and the Latin language, to name just a few important aspects of cultural writing. ${ }^{4}$

Considering writing on wood as a practice peripheral to the domain of culture, it becomes plausible that the most mundane of historical artefacts appears in medieval literary tradition primarily in circumstances that make such inscriptions unusual, becoming emblematic of the occult (Scandinavia), associated with a distant past and with antique practices of writing (Trojan War), or functioning as a form of cryptography (Tristan). The latter seems especially important to me. Since (apart from Scandinavia) writing on wood can be used for deceitful or encrypted messages, the acts of writing and reading are framed by this special mode of communication. Consequently, writing on wood means writing by yourself, with your own hands. Writing on wood is mostly clandestine, personal, and hidden from public view. There are no scribes lending a helping hand and no messengers carrying letters and messages around. Hence, writing on wood creates a distance between courtly and therefore high-value writing on the one hand and low-value writing on the other hand. That does not mean, however, that there is only courtly writing at the court. As we will see with regard to Tristan and Iseult, speaking of a "court" does not necessarily mean a certain place, but rather a concept that transcends a particular material space.

\section{Vergil and Ariosto}

It is worth emphasising-although probably not a complete surprise-that all my examples of inscriptions on wood deal with love attachment. Indeed, there seems to be a close bond between love and tree inscriptions reaching from antiquity until the present day. Passages from Vergil's Eclogues are particularly relevant and revealing, since they offer a narrative model on which many later texts rely. In the tenth and last eclogue, the Roman poet and politician Gallus mourns his beloved Lycoris, who has left him. In the course of his lament the desire to live the life of a shepherd also inspires him:

I'm going to go and measure songs that I've set down in verse of Chalcis with the Sicilian grazer's oat:

it's been decided to prefer to suffer in woods

among the wild beasts' lairs and cut into tender trees my loves: the trees will grow; you also, loves, will grow. (X, 50-54)

Here, "love" refers not only to the emotion, but also to a book of love songs Gallus wrote to mourn and remember his mistress (who crossed the Alps to the north with

4 For some reflections on the non-courtly sphere in German literature see Wenzel 1986. 
another man). ${ }^{5}$ Thus, the tenth eclogue contains a metafictional reflection on the relationship between poetical and pristine forms of writing, as well as between singing, music, and the performance of poetry in general. ${ }^{6}$ The reference to the growth of the trees introduces the question of posthumous fame; but it also addresses, on the most fundamental level, the notation and textualisation of the songs themselves. For textualisation provides the basis for a long-term reception. If poetry is meant to be permanently received, it has to be written down, somehow and some time.

Whereas Vergil marks one end of the above-mentioned void, Ludovico Ariosto's Orlando Furioso, published in 1516 marks, the opposite end. In this late heroic epic the traditional rules of the knightly world are largely overridden, and formerly typical behaviour and actions are now in vain. The passage I am referring to shows us the hero as a desperate lover-and, interestingly, as a reader not (as in Vergil's Eclogues) a writer. That is why the inscription(s) affect Orlando so profoundly.

As in the accounts of Tristan and Iseult, which we will examine later, there is a love triangle, namely between Orlando, Angelica and Medor. Orlando is in love with Angelica; but she hates him and loves Medor. In the twenty-third song, Orlando encounters numerous tree inscriptions with the names "Angelica" and "Medor" in a forest, some written in charcoal, some in chalk, and some scratched with the point of a knife. In the reasonably contemporary English translation of John Harington, completed in 1591, the relevant passage, worth quoting at length, reads as follows:

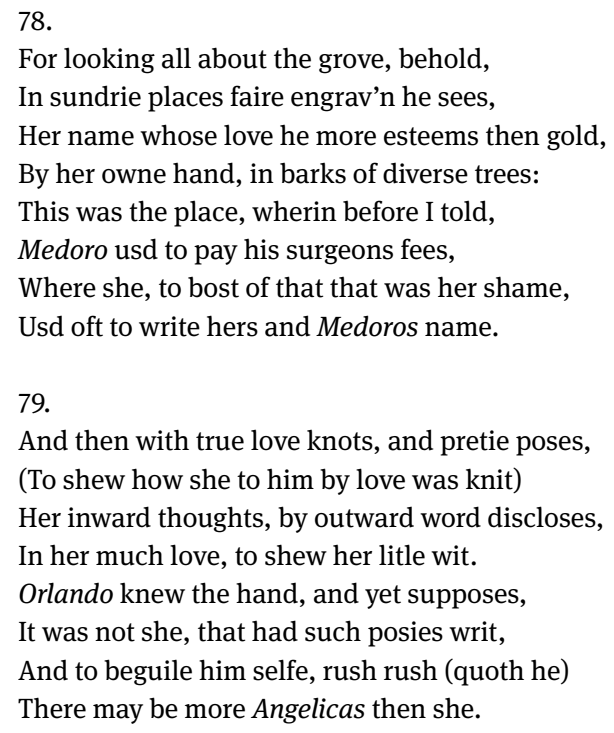

5 See Clausen 1994, 288ff.

6 See Breed 2006, 130. 


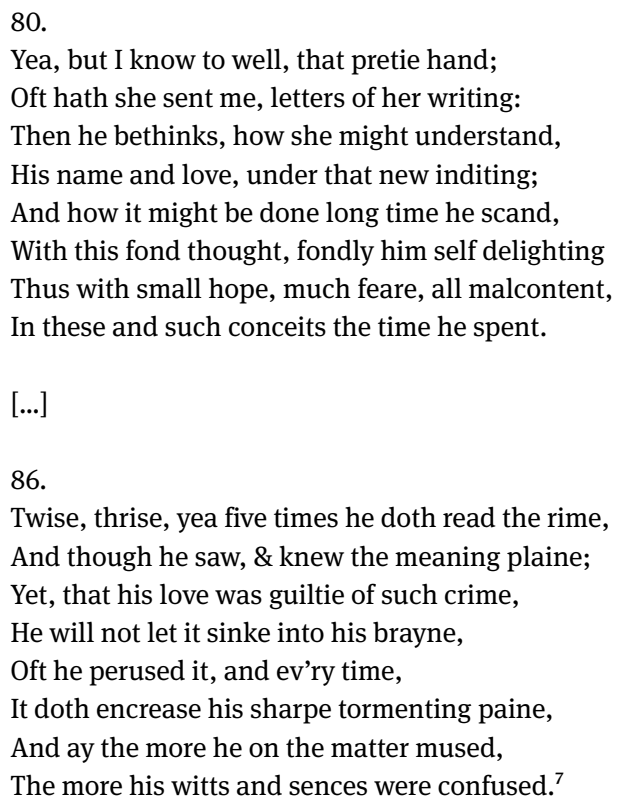

Even though Orlando recognises the handwriting and understands its implications, he still tries to somehow convince himself it is not true. He does not want the text to be literal but to be a code or a deceitful message, meant to delude him. So, at first, he considers the idea that Angelica might have decided to use the name Medor for his own, for Orlando. But this is just the beginning of his mental deterioration. The improbable idea does not last long and the written characters in the forest lead to an increasingly desperate series of interpretative acts. Finally, when a shepherd reports that Angelica has taken care of the injured Medor, Orlando goes mad and falls into furious rage.

Orlando's inchoate madness causes him to lash out at the natural world, attacking in particular the trees carrying the writing. As this is his answer to the handwriting of Angelica and Medor, he not only becomes a reader, but a writer himself, furiously unwriting the tree inscriptions with his sword in order to wipe clean the traces of the past rendezvous. His undoing of the text-bearing natural world, however, redounds upon him: by slashing the inscriptions, Orlando strikes out his chivalric identity as well, casting away his weapons and clothes. So, in the end, it is not only reading, that leads to his madness, but destruction of the cultural text that has been written into the woods.

7 Ludovico Ariosto, Orlando Furioso 1970, 183. I am transcribing "v" instead of "u” with regard to modern spelling. For modern prose see Ludovico Ariosto, Orlando Furioso 1994, $278 \mathrm{f}$. 


\section{Odin and the puella}

Orlando's frenzy in reaction to the letters inscribed in trees pales in comparison to the magical effects of runes in Old Norse poetry. Moreover, Orlando's crisis is precipitated by the information he learns by reading a script-bearing artefact. Madness as a result of an encounter with runic magic is a material effect of the script-bearing object itself; it is a psychic wound made by an occult weapon. Since this volume's article on Old Norse literature deals with runes and wooden inscriptions in detail, I will restrict my remarks to just one example, recounted by Saxo Grammaticus in his Gesta Danorum, which illustrates the magical quality of runes on wood.

Odin receives a prophecy from a magician that Rinda, the daughter of the Russian king, will bear him an avenger for his son Balder, who had been killed. Rinda, however, rejects his advances several times. Eventually, Odin strikes Rinda with a script-bearing wooden slat:

Odin, however, had found by experience that nothing served eager lovers more than a tough persistence, and although he had been humiliated by two rebuffs he altered his looks a third time and approached the king, claiming unparalleled competence in military arts. [...] Consequently the old veteran would give an admirable display of his professional skills by riding proudly to combat along with the most courageous. Despite this tribute the young woman remained inflexible. [...] When on one occasion, just before departing, he wanted to snatch a kiss from her, she gave him such a shove that he was sent flying and banged his chin on the floor. Immediately he touched her with a piece of bark inscribed with spells and made her like one demented, a moderate sort of punishment for the continual insults he had received. (III, 77)

The inscribed bark proves to be a very effective and reliable means of "punishment", showing the power of magical inscriptions. Eventually, now disguised as a woman skilled in the art of healing, Odin manages to bind sick Rinda to her bed and to father a son by raping her.

Such a magical power attributed to writing on wood is, as far as I can see, mostly absent in other medieval literary cultures. One possible exception is preserved in Carmina Burana, a thirteenth-century collection of Latin and German songs, some of which probably date back to the eleventh century. A stanza that is loosely linked to two others, but can nevertheless be read as a separate entity, offers a whole plot in just a few words:

Stetit puella bi einem bovme, scripsit amorem an eime lovbe. dar chom Venus also fram;

caritatem magnam, hohe minne bot si ir manne. (177,3 / 570f.)
A girl stood under a tree.

She wrote her love onto a leaf.

Then came Venus immediately.

Ample love, courtly love, she offered to her man. 
In his commentary on this stanza, Benedikt Konrad Vollmann points out that the girl probably writes a love-charm and that writing on the leaf leads to the instantaneous appearance of Venus. Vollmann also assumes that the girl writes the name of her beloved onto the leaf. ${ }^{8}$ If he is right, the girl does not write onto the leaf because it is conveniently at hand. The materiality of the artefact is actually relevant to the effectiveness of the writing, and the leaf is as an important material part of the charm.

The plucking of a leaf upon which to write highlights the fact that when it comes to writing on wood, one might speak of "biofacts" rather than artefacts. Biofacts, like bones or plants, may be considered as a subgroup of "ecofacts", of things that have developed naturally. ${ }^{9}$ The distinction stems from archaeology, but becomes relevant as soon as we leave the realm of artefacts behind. Like "geofacts" (e. g. stone and sediments), which form another subgroup, biofacts are not human-made but are merely and without much processing used by humans. Of course, the boundaries of this classification are fluid since it is hard to define at what point an ecofact, handled by humans, becomes an artefact. But the distinction is nevertheless helpful in order to think of the enmeshing of nature and culture that seems especially poignant considering writing on living wood in contrast to, for example, the prepared animal skin that constitutes parchment. ${ }^{10}$ As we see in the leaf inscription, there is no need to further prepare the leaf, no need to remake or alter it in order to use it for the intended purpose.

Even if the brevity of the Carmina Burana stanza forbids far-reaching conclusions, Ernst Doblhofer could be right when he observes at the end of his article on tree inscriptions, that "engraving the name of the beloved by the lover was the original custom" and that "name-charms and love-charms as two forms of superstition practiced in all times are originally behind the custom of carving names of the beloved in the bark of a tree". ${ }^{11}$ Certainly, one has to be careful in speculating via a few examples about the original reason for engraving names into trees. But it is safe to say that love and the arrangement of relationships has something to do with writing on wood and on trees in particular.

8 Carmina Burana, 1191. See the Minnerede B 255, Conversation between a Knight and a Lady: The lady faints, he writes amor vincit omnia on a rose leaf, and puts the leaf into her mouth. Immediately the lady gets back to health (Klingner/Lieb 2013, 387).

9 See Tsouparopoulou/Meier 2015, 49. The term ecofact was coined by Binford 1964, 432f.

10 For a reflection on skin as skin and parchment see Holsinger 2010.

11 Doblhofer 1996, 187 (my translation). 


\section{Oenone and Paris}

The story of Paris and Oenone is one particularly striking example of the way writing on wood participates in the negotiation of the romantic relationship. The Trojan War of Konrad von Würzburg probably gives the most important version of a tree inscription in medieval German literature of the thirteenth century. It is also the only example I know of that corresponds to common ideas of tree inscriptions, insofar as it is unambiguously an inscription engraved into the bark of a tree. Considering the source, however, Paris's inscription is not surprising, since it is featured quite prominently in Ovid's Heroides, where it is depicted from Oenone's point of view, of course. In the fifth letter, addressed to Paris, Oenone writes:

The beeches still conserve my name carved on them by you, and I am read there OENONE, charactered by your blade; and the more the trunks, the greater grows my name. Grow on, rise high and straight to make my honours known! O poplar, ever live, I pray, that art planted by the marge of the stream and hast in thy seamy bark these verses: IF PARIS' BREATH SHALL FAIL NOT, ONCE OENONE HE DOTH SPURN, / THE WATERS OF THE XANTHUS TO THEIR FOUNT SHALL BACKWARD TURN. $(59,21-30)$

Since trees are living plants, the continued growth of the tree does something to the text, making Oenone's name larger and her honour more famous. Consequently, the rather documentary tree inscription becomes a monument and-in Oenone's view-a public accusation. The concrete inscription stands witness to this accusation and so does the tree, the poplar, apostrophised by Oenone.

The story leading to the inscription is well known: Paris, who has been marooned since birth in the forest, meets the nymph Oenone, who falls in love with him and demands a sign of his love. Paris then, as Konrad von Würzburg's Der Trojanische Krieg says, does what lovers used to do in such a situation and cuts a text in the bark of a tree. His inscription declares:

"man sol daz wizzen hiute und êweclichen iemer mê, sô Pârîs und Egenoê von ir minne scheident und beide ein ander leident, sô muoz diz wazzer wunneclich ze berge fliezen hinder sich und widersinnes riuschen." (788-795)

\footnotetext{
"Today and forever it shall be known that when Paris and Egenoe [= Oenone] desist from their love, and no longer like each other, then this pleasant river must flow backwards up the mountain, streaming in opposite direction.”
}

Ironically, this explicit promise, which appears all the more powerful when considered in light of the inscriptions of love magic discussed earlier, is near the end of the relationship between Oenone and Paris. He leaves Oenone shortly after this "scene of writing”, awarding Aphrodite the famous apple and receiving Helen as a reward. 
The term "Schreibszene" (scene of writing), theorised in German Studies for quite some time now, is a useful concept to consider in relation to this scene. On the one hand, the term addresses the materiality and perception of writing as an intricate process, combining body, technique, material and tools. ${ }^{12}$ On the other hand, the concept of the "scene" highlights writing as a kind of performance, focusing attention on the representation of acts of writing, especially when writing becomes a problem and therefore an object of increased scrutiny. In terms of the Trojan scene, Paris uses a knife to cut "fine letters" (schœene buochstaben, 785) deep into the bark, thus creating not ephemeral and hasty marks, but a clear-cut document. For Oenone, who is explicitly said to have read the inscription, this has to look like a trustworthy act of faith, one that not only affects their relationship, but the course of nature.

Unfortunately for Oenone, the adynaton that refers to the impossibility of a river current flowing up a mountain is just a rhetorical gesture. And the act of inscribing a declaration of love is a mere gesture, too. The inscription as a staged scene of writing plays with expectations that are associated with tree inscriptions in general-in order to frustrate these expectations. Consequently, Paris's inscription is used here to emphasise not the beginning but the end of the relation between him and Oenone. The vow of love in the form of a tree inscriptions proves ineffective, for while Paris's act of writing may serve to reassure the amorous nymph, it does not create any reliable relationship, and certainly no reliable outlook on the future.

Finally, and perhaps even more significant: the nature of the text has changed. Time repurposes the words. What was a private declaration of love (addressed to the broader natural world, yes, but not a human community) has now become a public text, a historical monument attesting to Paris's betrayal and Oenone's suffering to society at large. Interestingly, the inscribed tree's role as a historical monument expands to represent the Trojan past itself in Walter of Châtillon's Alexandreis when Alexander, eagerly seeking traces of early antiquity, discovers Oenone's poplar. ${ }^{13}$

\section{Tristan and Iseult}

Wooden inscriptions are much more reliable as a means of communication between lovers in stories about Tristan and Iseult. Actually, as Urban Küsters has noted, "in texts about Tristan from the high-medieval period, pieces of wood are the preferred material in order to arrange secret rendezvous against the opposition of the inimical

12 See Campe 1991. And see several publications by Martin Stingelin, for example the collection: Stingelin/Giurato/Zanetti (eds.) 2005.

13 Dumque uetustatis saltim uestigia querit / Sedulus, obicitur fluuiali consita riuo / Populus Oenones, ubi mechi falce notate / Scripta latent Paridis tenerique leguntur amores (I, ch. V, 457-460). 
supervision". ${ }^{14}$ Desperate times require the spontaneity afforded by biofacts, at least when love is involved. In order to arrange undisturbed meetings while under constant surveillance you have to use encrypted communication and appropriate media. That is why you need a convenient material, quickly acquired, easily inscribed, and inconspicuous. Once again the distinction between nature and culture is significant. Nobody expects to "read" things that are part of nature, even without encryption. Wooden messages are hiding in plain sight because of assumptions about writing as a quintessentially cultural artefact.

In Gottfried von Straßburg's German version of the legend, the brilliant idea to use wooden shaving to communicate comes not from Tristan, but from Brangaene. After all, her essential task throughout the novel is to help; and so she, more than any other character, is responsible for the secret contacts between the lovers. "'Since there is nothing better to do,"” she says,

'take my advice, nevertheless, for now and so long as you are separated from us. When you see that your chance has come, take a twig of olive, cut some slivers lengthwise, and just engrave them with a "T" on one side and an "I" on the other, so that only your initials appear, neither more nor less. Then go into the orchard. You know the brook which flows there from the spring towards the ladies' apartments? Throw a shaving into it and let it float past the door where wretched Isolde and I come out at all times of the day to weep over our misery. [...]' (14421-14444) ${ }^{15}$

Brangaene's suggestions make use of the topography offered by the cultivated nature at (or near) the court. The message is quite simple, almost binary code, since agreeing on specific signs and a specific channel reduces the "noise" (read: the disturbance) in the transmission of a signal. Additionally, the engraved shavings feature a symbolic and iconographic dimension. Tristan and Isolde are united via the initials in the narrow space of the shavings, while the chips in the water are reminiscent of their crossing of the Irish Sea. But despite the writing and symbolism, the labelled chips are inconspicuous within the orchard's cultivated nature. In order to expect such a wooden message you have to know the code, you have to know what to look for. Seen as a form of communication, the wooden shavings have a low degree of publicity, much lower than framed inscriptions of names in publicly accessible trees.

In Gottfried's Tristan, the choice of written characters (on wood) for the transmission of the signal depends also on the specific artistic characteristics of this romance. Apart from the text's acrostics, the written characters especially recall the poem's juxtaposition of the lovers, as for instance in lines 129f.: ein man ein wîp, ein wîp ein man, / Tristan Isolt, Isolt Tristan. These semiotic possibilities, put into practice by Gottfried von Straßburg's palindromes, are evoked by Tristan's inscription as well.

14 Küsters 1996, 71 (my translation). Küsters describes new developments concerning the authentication of charters (via crosses, monograms, specified colours). These developments may be reflected in the various examples of shibboleths in accounts of Tristan and Iseult.

15 Concerning the combination of “T” and "I” see Klingenberg 1974, 145. 
Interestingly similar to the encryption of the engraved slivers is Marie de France's account of the Tristan and Iseult story in Chevrefoil, Marie's shortest lai. ${ }^{16}$ Tristan, who has been exiled by his uncle Mark, hears about a feast at Tintagel that Mark is planning. Since Iseult will be present, too, Tristan contacts her during her voyage:

Le jur que li reis fu meüz,

Tristram est el bois revenuz.

Sur le chemin que il saveit

Que la rute passer deveit,

Une codre trencha par mi,

Tute quarreie la fendi.

Quant il ad paré le bastun,

De sun cutel escrit sun nun.

(47-54)
On the day the king set out, Tristram entered the wood along the road he knew the procession would have to take. He cut a hazel branch in half and squared it. When he had whittled the stick he wrote his name on it with his knife.

Iseult, who keeps an eye out for the signal, spots the hazel branch and tells her company to halt. She pretends to go for a walk in order to rest, accompanied by her handmaiden Brenguein, and so manages to meet Tristan.

Much has been written about Marie's narration and the inscription in particular. In fact, this might be the most famous inscription on wood in medieval literature. And yet, the inscription is mostly discussed with regard to real-world phenomena, like tally-sticks and Ogham script. ${ }^{17}$ To be sure, considerations of the material are important, since most of modern readers do not know much about hazel rods or honeysuckle. Basic commentaries on botanical characteristics, as provided for instance by William Sayers, help to regain cultural knowledge about the natural world likely familiar to medieval audiences.

In addition to such materially-specific considerations, I would argue that the conceptual opposition between nature and culture that informs how we perceive writing on trees, and on wood in general, also lurks behind Marie's lai. Hence, the narrative carefully embeds the inscription into a web of activities of high cultural significance. Chevrefoil includes, "ingenuous tale and romance, written message and song, known story and new signification, in a variety of media: memory, ordinary speech, artistic language, writing on wood and on vellum". ${ }^{18}$ These cultural activities contain and enclose the inscription, metamorphosing mundane acts of everyday communication into culturally prestigious writing.

This transformation also explains why Marie's Tristan does not merely write on a tree or bush. His writing is not a spontaneous act but a cultural exercise. He deliberately chooses the material carrier of his message with regard to its symbolic value. He also carefully prepares the material, making it more an artefact than biofact,

16 Marie de France's lai has been translated into Old Norse. See Geitarlauf, in: Strengleikar, 196-199. 17 See, in particular, Sayers 2004.

18 Sayers 2004, 3. 
challenging the boundary between nature and culture. In the end, the hazel rod with its inscription stands out for those who know what to look for. And it remains hidden for those who cannot see culture in nature.

\section{Works Cited}

\section{Primary Sources}

Carmina Burana (1987), ed. by Benedikt Konrad Vollmann (Bibliothek des Mittelalters 13), Frankfurt am Main.

Galterus de Castellione [Walter of Châtillon] (1978), Alexandreis, ed. by Marvin L. Colker (Thesaurus Mundi 17), Padua.

Gottfried von Straßburg (1988), Tristan and Isolde, trans. by A. T. Hatto, rev. by Francis G. Gentry, New York.

Gottfried von Straßburg (2004), Tristan, ed. by Karl Marold, trans. by Peter Knecht, Berlin/New York. Konrad von Würzburg (1858), Der Trojanische Krieg, ed. by Adelbert von Keller (Bibliothek des litterarischen Vereins in Stuttgart 44), Stuttgart, reprint Amsterdam 1965.

The Lais of Marie de France (20032), trans. by Glyn S. Burgess/Keith Busby, London et al.

Ludovico Ariosto (1970), Orlando Furioso. In English heroical verse [by John Harington]. (The English experience 259), Amsterdam/New York.

Ludovico Ariosto (1974), Orlando Furioso, trans. by Guido Waldman, London/Oxford/New York.

Marie de France (1966), Lais, ed. by J. Rychner (Classiques français du moyen âge 93), Paris.

Marie de France (1980), Die Lais, trans. by Dietmar Rieger (Klassische Texte des romanischen Mittelalters 19), München.

Ovid (1963), Heroides and Amores, trans. by Grant Showerman, Cambridge.

Saxo Grammaticus (1998), The History of the Danes. Books I-IX, ed. by. Hilda Ellis Davidson, trans. by Peter Fisher, Cambridge.

Strengleikar. An Old Norse Translation of Twenty-one Old French Lais (1979), ed. and trans. by Robert Cook and Mattias Tveitane (Norrøne tekster 3), Oslo.

Virgil (2011), Virgil's Book of Bucolics, the Ten Eclogues. Translated into English Verse. Framed by Cues for Reading Aloud and Cues for Threading Texts and Themes, trans. and ed. by John Van Sickle, Baltimore.

\section{Secondary Sources}

Binford, Lewis R. (1964), “A Consideration of Archaeological Research Design”, in: American Antiquity 29, 425-441.

Breed, Brian W. (2006), Pastoral Inscriptions. Reading and Writing Virgil's Eclogues (Classical Literature and Society), London.

Campe, Rüdiger (1991), “Die Schreibszene. Schreiben”, in: Hans Ulrich Gumbrecht and Karl Ludwig Pfeiffer (eds.), Paradoxien, Dissonanzen, Zusammenbrüche, Situationen offener Epistemologie, Frankfurt am Main, 759-772.

Clausen, Wendell (1994), A Commentary on Virgil, Eclogues, Oxford/New York. 
Doblhofer, Ernst (1996), “'Ich schnitt’ es gern in alle Rinden ein'. Zur Geschichte eines antiken Motivs", in: Antike und Abendland 42, 174-188.

Holsinger, Bruce (2010), “Parchment Ethics. A Statement of More than Modest Concern”, in: New Medieval Literatures 12, 131-136.

Klingenberg, Heinz (1974), "Si las Isot, si las Tristan. Das Kreuz im Tristan Gottfrieds von Straßburg", in: Alfred Ebenbauer, Fritz Peter Knapp and Peter Krämer (eds.), Strukturen und Interpretationen. Studien zur deutschen Philologie gewidmet Blanka Horacek zum 60. Geburtstag (Philologica Germanica 1), Vienna/Stuttgart, 145-161.

Klingner, Jacob/Lieb, Ludger (2013), Handbuch Minnereden, 2 vols., Berlin/Boston.

Kruschwitz, Peter (2010), “Writing On Trees. Restoring a Lost Facet of the Graeco-Roman Epigraphic Habit”, in: Zeitschrift für Papyrologie und Epigraphik 173, 45-62.

Küsters, Urban (1996), “Späne, Kreuze, Initialen. Schriftzeichen als Beglaubigungsmittel in mittelalterlichen Tristan-Dichtungen”, in: Dirk Matejovski and Friedrich Kittler (eds.), Literatur im Informationszeitalter (Schriftenreihe des Wissenschaftszentrums Nordrhein-Westfalen 2), Frankfurt am Main/New York 1996, 71-101.

Neukirchen, Thomas (1999), Inscriptio. Rhetorik und Poetik der Scharfsinnigen Inschrift im Zeitalter des Barock (Studien zur Deutschen Literatur 152), Tübingen.

Pierce, Marc (2006), "The Book and the Beech Tree Revisited. The Life Cycle of a Germanic Etymology”, in: Historische Sprachforschung/Historical Linguistics 119, 273-282.

Sayers, William (2004), “Marie de France's Chievrefoil, Hazel Rods, and the Ogam Letters Coll and Uillenn”, in: Arthuriana 14, 3-16.

Stingelin, Martin/Giurato, Davide/Zanetti, Sandro (eds.) (2005), "SCHREIBKUGEL IST EIN DING GLEICH MIR: VON EISEN”. Schreibszenen im Zeitalter der Typoskripte (Zur Genealogie des Schreibens 2), München.

Tsouparopoulou, Christina/Meier, Thomas (2015), “Artefakt”, in: Thomas Meier, Michael R. Ott and Rebecca Sauer (eds.), Materiale Textkulturen. Konzepte - Materialien - Praktiken (Materiale Textkulturen 1), Berlin/München/Boston.

Wenzel, Horst (1986), "Ze hove und ze holze - offenlîch und tougen. Zur Darstellung und Deutung des Unhöfischen in der höfischen Epik und im Nibelungenlied", in: Gert Kaiser and Jan-Dirk Müller (eds.), Höfische Literatur. Hofgesellschaft. Höfische Lebensformen um 1200. Kolloquium am Zentrum für Interdisziplinäre Forschung der Universität Bielefeld (3. bis 5. November 1983) (Studia humaniora 6), Düsseldorf, 277-300. 